\title{
An Interpretation of The House on Mango Street from the Perspective of Self Consciousness and Patriarchy
}

\author{
Shaojun Duan \\ School of Foreign Languages \\ Kunming University \\ Kunming, China \\ Email: duanshaojun2709@126.com
}

\begin{abstract}
Sandra Cisneros is an outstanding contemporary poet, a Mexican writer. Her novel The House on Mango Street tells us a story about the life of a poor Mexican girl living in Chicago community. The protagonist of this story is a teenage girl, and the author narrates her stories, including the mental journey, growing up experience and exploring inner experiences by herself during the stage of growth. This paper is going to explore the construction and awaking of Esperanza's self-consciousness, and her voiceless resistance of patriarchy under the guidance of the theories about self-consciousness and patriarchy. It finds out according to her surrounding environment, Esperanza builds up her selfconsciousness and cognition of the world which inspires her to revolt the patriarchy. The author of this paper hopes this paper may shed some light on the study of this novel and offer some help to those young girls like Esperanza in our daily life
\end{abstract}

Keywords: The House on Mango Street; growth; self consciousness; feminism; patriarchy

\section{INTRODUCTION}

Sandra Cisneros was born in 1954 in Chicago to a Spanish-speaking Mexican father and an English-speaking mother of Mexican descent. Cisneros was the third child and only a daughter in her family, she had six brothers. She spent most of her childhood in the Chicago's Puerto Rican neighborhood, at that time, she and her family traveled back and forth to American and Mexico. The life moving from place to place and Mexican immigrants' marginal status made her difficult to stay with her friends for a long time. So her character became introverted and shy. In her childhood, she had learned to observe people's behavior, and wrote down it on her notebook. Her living environment and inner experiences during the stage of growth provided her many writing materials and led her to show lifelong concern for the women of Mexican descent. At her thirties, she was well-known for her work The House on Mango Street, besides this, Cisneros has published two books of poetry, My Wicked Ways and Loose Woman. The Chinese scholar Li Daoquan once commented Sandra Cisneros, Amy Tan and Toni Morrison were all successful writers at the end of the twentieth century. Many of them had been writing for some time about the renewed interest in the issues of race and gender in the 1980s, which provided a milieu for their work. ${ }^{[1]}$

In the 1990s, many scholars in American begin to make a research on Cisneros's "The House on Mango Street". Allen Michaela Ken proposes that Sandra Cisneros changes the traditional patterns of male writing growth novel and from the feminine perspective to write the pursuit of a kind of collective identity. ${ }^{[2]}$ In the1992, De Valdes confirms the relevancy of the heroine in novel and the author's experience. At the same time, the focus of studying shifted from the theme of growth to double marginalization. ${ }^{[3]}$ Early in 1994, Jacqueline Doyle published an article in which she focuses on the problem of minority ethnic. She compares "The House on Mango Street" to Virginia Woolf's "A Room of One's Own", and then points out that the female writer of minority ethnic faces more difficult in the progress of writing than the white women. ${ }^{[4]}$ Anne O Eysturoy (1996) discusses the identity, gender, and class during the stage of the heroine self-creation. ${ }^{[5]}$ In the1998, Critics attached great importance to Esperanza's ethnic and gender identity. In the 21 st century, this trend spreads to China as the western critical circle turns to Cisneros's new works. There are many scholars studying Cisneros's works in China. In general, their research achievements include four groups: The first group mainly focuses on the Cisneros's life. The second group deals with the styles and features of her writings and appreciation of her masterpieces. The third group researchers mainly study the female images and the Esperanza's growing up experiences in "The House on Mango Street" through the theory of feminist perspective. The final group is to explore some social problems, such as racial discrimination, female freedom, gender inequality, and females' awareness of revolting the patriarchy. This paper is going to explore the construction and awaking of Esperanza's self-consciousness, and her voiceless resistance of patriarchy under the guidance of the theories about self-consciousness and patriarchy. It finds out according to her surrounding environment, Esperanza builds up her self- consciousness and cognition of the world which inspires her to revolt the patriarchy. The author of this paper hopes this paper may shed some light on the study of this novel and offer some help to those young girls like Esperanza in our daily life.

\section{THEORETICAL FRAMEWORK}

\section{A. Self-consciousness}

Growth is an eternal topic of the mankind. It is one of the processes that everyone has to experience. Growing up novels pay close attention to theme of teenagers' inner life experience, the conflict between the social reason and social value and the problem of the self-awareness and 
construction in teenagers' growth stage. The Younger' growth is a kind of social transformation, that is to say, the teenagers said goodbye to the carefree childhood, their self-consciousness was awakened, and they were eager to become mature and independent. In this growth stage, they were also desire to be understood, possess the friendship and know the true meaning of life. All of these teenager's inner experiences were in constant collision processes during which the youths became ripe, mature from the childish naivety. In The House on Mango Street, the protagonist's growth process is an awakening and constructive to the self-awareness.

\section{B. The Theory of Patriarchy}

Patriarchal (Patriarchy) means a male as the center of power. In English Patriarchy can refer to the patriarchal, patriarchal system and the parents are the rulers in a family. In Chinese we usually don't distinguish them [1].

The feminist theory was used too much in the past time, and it is the American writer Kate Millet who is the earliest writer to introduce the theory of patriarchy into feminist theory. This concept appears in her masterpiece sexual politics, thus the patriarchy is a new beginning compared to the feminist theory. She thinks that the root of women suffering oppression is the "patriarchy", which puts the female and the male in a completely opposite situation. The original meaning of "Patriarchy" refers to the system of social relations of the father as the powerful centre, and Millet adds to the new meaning for it: Firstly, the male dominates the female; secondly, the male elders dominates junior [1]. In the $1960 \mathrm{~s}$, this concept is defined as the systematic system of male superiority and female inferiority.

\section{THE CONSTRUCTION AND AWAKING OF ESPERANZA'S SELF-CONSCIOUSNESS}

\section{A. The Poverty}

The reason why Esperanza's family moved into the Mango Street was that landlord refused to repair the broken pipes in their formerly house. Before they moved into the house on Mango Street, she and her family had moved for a lot of times. She dreams of a white house with a large space and a lot of bathrooms. However, the house on Mango Street has only one bedroom and one small bathroom. When she moved into the house, Esperanza founds that it is not the house that she envisioned. Although her parents told her it is a short transitional period, she doubted they still need to move into other places in someday. She knows the house on Mango Street is better than the previous apartment, because her family owns the house. It's no longer belonging to the landlords. What's more, they don't need to pay rent to the landlords, or be afraid of making too much noise in house, or sharing the yard with the neighbors, and so on. Though for now, the house has some significant advantages more than her previous apartments, the house has broken her beautiful fantasy and it is still not the house that Esperanza wants to point out as hers. Esperanza even admitted that she has a kind of sense of shame living there. Her father is a poor gardener, and her mother is a housewife without too much education experience. These observations stimulated her childish heart. To some extent, these observations and her inner experiences also arouse her thinking of the fates of Mexican women and herself in future, and she wants to have house all her own.

\section{B. Esperanza's Awareness of Racial Differences}

In the chapter of "My Name", Esperanza always meditates on the meaning of her name. In English her name means "hope," on the contrary, in Spanish her name means "too many letters," as well as "sadness," "a muddy colors" and "waiting", which are all meaningful symbols. Esperanza says that her long name of polysyllable is from the Spanish. In the school of America, her classmates thought Esperanza's name is weird and funny. As the Mexican immigrant she has to face these problems between the ethnic traditional culture and the real world, either to make a compromise with the real world or to pursue her dreams. Esperanza understands that she belongs to "brown race".

In the section of Cathy Queen of cats, Kathy is very friendly who offered to introduce her local neighborhoods and shops in the barrio. However, she still has a kind of superiority, and she brags about her French relatives and the house in France. Though Cathy does not make clearly racist comments about the Esperanza, she understands that the comment relates to her, so Esperanza thinks Cathy is rude. Cathy says that the arrival of nonwhites would reduce the grade of the community and her family has to keep moving further away these families like Esperanza's family. All these words were spoken out from the tongue of a child, which cruelly reflects the contradiction, ills and prejudice of the adult society. The awareness of Esperanza's racial differences awakes up suddenly.

\section{Esperanza's Awareness of Feminism}

In "The House on Mango Street", Cisneros used many words to describe the consciousness of Esperanza's feminism. Sensitive Esperanza found early that the boys and girls lived in separate world. The boys lived in their universe, and we in ours. She can talk with her brother at home, outside, even her younger brother also refused to talk with her. So Esperanza must socialize with her sister Nanny. In this world, the women often suffered gender discrimination.

Marian is a young beautiful woman from Puerto Rico who lives with her cousin's family. She spends most of her time to take care of the baby of her cousin's family, so she cannot leave the house. Marian doesn't like this kind of life, she wants to change it. So the only thing she can do is "under the streetlight, dancing by herself" [6]179, waiting for a man from America who will take her to leave here and change her life, however, he never came here.

Lupe is Esperanza's aunt with an incurable disease, who had been looking forward to the coming of the god of the death, because she was tortured by the sickness, and the sickness made her can't perform the responsibility and obligation as a wife and mother. Her children don't want to wash the dishes, and don't want to iron father's clothes. Therefore, she feels ashamed and upset when she thought about her husband who wants to marry another woman. 
There is no doubt that her weak body bearing the female virtues of docile, loving and self sacrifice. And all of these female virtues are highly praised in patriarchy society. These kinds of old gender discrimination and absurd behavior methods stimulate Esperanza's thinking. She hates this kind of conception. At the same time, the conception of the feminist and independence is taking root and growing in her heart.

\section{Esperanza's Construction of Self-consciousness}

At the beginning of the story, Esperanza just wants to possess house of her own, to get out of poverty, and to leave the Mango Street. Esperanza whispered one of her own poems in Lupe's ear. Then Lupe told her that she should keep writing because it will make her free. The word freedom catches the eye of Esperanza, but freedom does not mean that getting out of the barrio. At first, she doesn't understand what the meaning of the sentence that Alicia says " like it or not you are from Mango Street, and one day you'll come back too" ${ }^{,[6] 276}$, so Esperanza answers that she doesn't want to come here until somebody makes it better. Then Alicia asks who will make it better, suggesting the mayor as the possibility. Esperanza immediately understands that she just gets out of the poverty in Mango Street, not the Mango Street. Eventually, at the end of the novel Esperanza knows that one day she will leave here with her books and writing materials, but she will have to leave for the purpose that she would come back for the people who cannot get out of Mango Street. Esperanza finally realizes that she really wants to change the life of herself and the people who often suffer the racial discrimination like her, and she loves them, so she wants to help the people of Mexican descendant, especially the Mexican women. Esperanza begins to accept her position in her community and decides that the most important way she can define herself is as a writer, this is a kind of pursuit of self -value.

\section{THE HEROINE’ S VOICELESS RESISTANCE OF PATRIARCHY}

\section{A. Father Being Women's Direct Oppressor in a Family}

The Heroine Esperanza in The House on Mango Street uses her pure eyes to observe the world in her growth process. In this process, Esperanza going through her inner experience and the interaction with the surrounding environment and the ethnic group has formed a different dream from others. She realizes that if she wants to completely get rid of the oppression from patriarchy, she has to wait patiently. In addition, Esperanza makes a determination to use writing as the method of voiceless resistance to win the respect, and to help those people who can not come out from the dilemma like her.

Father is a specific representative in the patriarchy society. In a family, father possesses a paramount power, being women's direct oppressor, and Marin is one of the victims. Marin on one hand hopes to stay in Chicago one more year so that she can get a job as the white-collar in downtown. On the other hand, she hopes to meet a rich man owning driving car and having a big house who will marry her and take her to leave the barrio. However, the concept of the family in the patriarchy forces Marin to stay at home to look after Louie's sisters. She is located at the bottom in Louie's family, and enslaved in the society and economy, without any power of dominating her own destiny and family. Under the system, the women belong to the subordinate status, and always was oppressed and dominated by the men, becoming the victims of the patriarchy. Therefore, only in the evenings, when Marin's uncle and aunt went to sleep, she could temporarily get rid of this kind of bondage; she takes her radio outside and dances under the streetlight, lighting up a cigarette, and waiting for boys to come here. Her behavior is not just for attracting a man but more for being a kind of abreaction and comfort under the oppression of the patriarchy.

\section{B. Women Being Regarded as Men's Accessories}

In the patriarchy society, women are regarded as men's accessories, and the women don't enjoy the equal rights like the men. In the Mango Street, the women suffering the oppression of patriarchy can be found in everywhere. Esperanza has the same name with her great-grandmother, "so wild she wouldn't marry. Until my great-grandfather threw a sack over her head and carried her off. Just like that, as if she were a fancy chandelier. That's the way he did it" [6]160. Then she never forgives him, and spends her life looking out the window and longing for escape. Great-grandmother chooses the resentment which is the method of voiceless resistance to win the respect, and to fight against the fate.

History sometimes can replay during the long developing process of human beings. Like Espranza's great-grandmother, Rafaela is also one of the women spending their lives looking out of the window and longing for escape. Rafaela is so beautiful that her husband often locks her in their third-floor apartment, because he's afraid she'll escape. This is a kind of ruthless deprival of the freedom of women, reflecting the female's inferior position in a family. On Tuesdays, she spends these afternoons and evenings leaning out of the window, which makes her prematurely old. In her deep heart she wants to go to the bar down the street to have a dance while she is still young, but instead she has to drop a dollar out of the window so that Esperanza and her friends can buy her some coconut or papaya juice at the store, which Rafaela then hauls up on a clothesline. At the bar, women who are older than Rafaela are allowed to dance and flirt, but each risks being imprisoned in the same way as Rafaela. It is obvious that her husband regards her as a precious thing by locking her in the safe box. It is a kind of life without personality, dignity and freedom for Rafaela. But she is yearning one day she can go to the pub at the bar down the street and dreams of one day the clothesline becoming a silver clothesline. Poor Rafaela doesn't realize that she is in the mechanism of subordinate private property, just escaping from a cage and jumping into another more elegant one. Every day Rafaela drinks coconut and papaya juice symbolizing her good expectations for life. She is becoming old day by day, and in her life there is always a patriarchal chain ruling her which she never cannot get rid of it. 
Sally's life inspires Esperanza's thinking. When Esperanza helps Sally to look for a way to escape the patriarchy she realizes that she is also finding a way to escape from here, and this is a realistic problem that she must to face. Sally is very beautiful, wearing Cleopatra's makeup, nylons and short skirts. Her father thinks her beauty is dangerous and doesn't let her go out of the house. Esperanza understands now why Sally is reluctant to go home after school. In the late story Sally finally left the mango street and married to a salesman living in another state. Sally declares that she is in love, but young Esperanza feels that Sally's behavior is a kind of escaping. Sally's life has been improved economically, yet her husband's temper resembles her father, who will kick the door if angered. Furthermore Sally's husband does not let her chat by telephone, make friends with others and look out of the window. Looking out of the window is the last bit of freedom for most of the trapped women Esperanza knows, including Mamacita, Marin, and Rafaela, but poor Sally is not even allowed to do that. Sally tries to change her life through the marriage at the very beginning, but in the end she still can't get rid of the oppression of the patriarchy, being fated to a life of looking at the artificial roses on her linoleum floor.

\section{Getting Rid of Patriarchy in the Process of Waiting}

Esperanza, the heroine of the novel witnesses the trapped women's lives in her growth process and all of the things arouse her inner reflection. Her capacity for both empathy and pity grows as she understands their particular stories, and from these women's lives, Esperanza gets a precious experience about how to help the trapped women. Because Esperanza does not want to leave the women behind in a dangerous place the way Sally left her, Esperanza's voiceless resistance has more power of struggle. Esperanza not only refuses to accept the definition and expectation of patriarchy society for women but also chooses the method of accepting education to improve her capability. Through the method, she gradually steps into the mainstream society dominated by the whites and becomes an independent individual, so as to shake off the rule of the patriarchy. The voiceless resistance to the patriarchy from her self-consciousness is slowly constructed during her stage of growth. At the beginning of the novel, she believes she will be a red balloon. She feels she is floating in anticipation of something and that she feels isolated and cannot escape from the family responsibility and the ruling of the patriarchy. When Esperanza reads her poems to her aunt Lupe who is a real fortuneteller with an accurate prescription for escaping the barrio through hard work, she gets an encouragement from her aunt. In the meantime, Esperanza has a new understanding for her responsibility, which inspires her adherence to writing and accepting education. Through this way she can obtain the dream of finding a real house just belonging to her, "Not a man's house. Not a daddy's" [6]279.

During the stage of her growth, Esperanza dares to explore a new feasible road, allowing the development of her natural instincts, stimulating the various possibilities of her inner experiences, and opening up the new space for the women's survival, which can let her obtain the full experience of life. It is very important for her during her growth to depend on the knowledge to change destiny. In addition, this is a victory that Esperanza completely frees herself from the ruling of the patriarchy and it is also the results of the voiceless resistance and the patient waiting. Because she has already made up her mind to fulfill her dream, "I have begun my own quiet war. Simple. Sure. I am one who leaves the tables like a man, without putting back the chair or picking up the plate" [6]120. She will completely become independent away from the patriarchal domination, becoming a writer of both independence and social responsibility, and a spokesman and leader of Hispanic population, especially the women under the ruling of patriarchy. She will use her article to record her story, and to inspire thousands of Mexican women to get rid of the bondage physically and spiritedly, and let the trapped women know that the self-reliance is so important for them. Through her story, she also wants to change the foolish traditional ideas of exploitation and controlling by male, opening up a new space for women's survival.

\section{CONCLUSION}

The House on Mango Street received a warm popular applause after it was published for one year. Cisneros gained the Columbus Foundations American Book Award, and her work "The House on Mango Street" was collected into The Norton Anthology of American Literature. After this, it was collected into the textbooks of the primary and high school in America, and became the most famous classic growth novel of contemporary America, and won a high praise from the academic. In the work, you will strongly feel the painful situation of being excluded of the Mexican descendants, especially the Mexican woman who lives in the white- dominated culture. In addition, you can also see the outdated idea of contemning females, and the male dominated center which is deeply rooted in Mexican culture. Esperanza is a little girl living in the Mango Street with the people who come from the same nationality, but she has different growth experience, dream, and the mental journey, exploring inner experiences by herself during the stage of growth. So Esperanza doesn't want to become this kind of women like the trapped women in The House on Mango Street who spend their lives looking out of the window and longing for escape, and she also witnesses those women who want to change their fates through the marriage. On the basis of these experiences of her, this article mainly focuses on the construction of Esperanza's self-consciousness during the stage of her growth, which inspires her to shake off the rule of the patriarchy. Aiming at raveling Esperanza's and other Mexican women's marginal status in American society and their subordinate reality to their fathers or husbands, the work lays bare those Mexican women's physical and spiritual pursuit of revolting the patriarchy, racial, and gender identity. ${ }^{[7] 118}$ In addition, the patriarchy would facilitate the feminist move all over the world and incent the minority ethnic groups to work hard and acquire knowledge in order to change their destinies. And hopefully, in daily life women can refuse to 
accept the definition and expectation of patriarchy society for women and have the independent consciousness.

\section{REFERENCES}

[1] L. Daoquan, "Departure and Return: Writing of Immigrant Communities in A House on Mango Street," in Language and Literature,vol. XII, W.Jinkuan, Eds. Shenyang: Journal of Northeastern University(SOCIAL SCIENCES), 2010, pp 273-277.(in Chinese)

[2] A. Horono-Delgado, P. Eliana Ortega, Breaking Boundaries: Latina Writing and Critical Readings. Amherst: The University of Massachusetts Press, 1989.

[3] P. Harold Bloom, Bloom's Modern Critical Interpretations: The House on Mango Street. New York :Infobase Publishing, 2010.

[4] J. Doyle, "More Room of Her Own: Sandra Cisneros's The House on Mango Street,"in Melus, vol. XVIIII, P. Schmidt, Eds. Oxford:Oxford University Press, 1994, pp. 5-35.

[5] AO Eysturoy, Daughters of self-creation : the contemporary Chicana novel,New Mexico: University of New Mexico Press, 1996.

[6] S. Cisneros, The House on Mango Street(English to Chinese), Nanjing: Yilin press, 2008.(in Chinese)

[7] W. Haiyan, "A house of his own: class, ethnic, and female identity, a review of Cisneros' The House on Mango Street," in Literature, vol. XX, L. Yanping, Eds. Xian:Journal of Xi'an Electronic and Science University (SOCIAL SCIENCE),2010, pp. 113-118.(in Chinese) 